\title{
PENINGKATAN HASIL BELAJAR MATEMATIKA MELALUI PEMBELAJARAN PENEMUAN
}

\author{
Wulan Perawati \\ STAI Darunnajah Jakarta \\ wulanperawati@gmail.com
}

\begin{abstract}
This study aims to determine how the learning process in improving students' mathematics learning outcomes through discovery learning. In addition, this study also aims to determine the improvement of students' mathematics learning outcomes through discovery learning. This research was conducted on the second grade students of MI Ishlahuddiniyyah, Pondok Aren District, Tangerang in the 2012/2013 academic year. The method used in this study was action research developed by Kemmis and Taggart. The data analysis used in this study was carried out in two ways, namely quantitative and qualitative approaches. Quantitative analysis shows that there is an increase in students' mathematics learning outcomes starting from pre-research to cycle I, which is $31.87 \%$. Based on the agreement between the researcher and the collaborators, the success of the action can occur if there is an increase in students' mathematics learning outcomes of at least 20\%. In this study, the increase in students' mathematics learning outcomes has succeeded in exceeding $20 \%$, thus the research hypothesis can be accepted. The results showed that the application of discovery learning steps in the mathematics learning process was proven to improve students' mathematics learning outcomes. In this case, the concepts of abstract mathematics subject matter can be better understood by students with direct experience and active involvement of students in the discovery learning process (learning by doing).
\end{abstract}

Keywords: Mathematics learning outcomes, discovery learning, action research 


\begin{abstract}
ABSTRAK
Penelitian ini bertujuan untuk mengetahui bagaimana proses pembelajaran dalam meningkatkan hasil belajar matematika siswa melalui pembelajaran penemuan. Selain itu, penelitian ini juga bertujuan untuk mengetahui peningkatan hasil belajar matematika siswa melalui pembelajaran penemuan. Penelitian ini dilakukan terhadap siswa kelas II MI Ishlahuddiniyyah, Kecamatan Pondok Aren, Tangerang tahun ajaran 2012/2013.Metode yang digunakan dalam penelitian ini adalah penelitian tindakan (action research) yang dikembangkan oleh Kemmis dan Taggart. Analisis data yang digunakan pada penelitian ini dilakukan dengan dua cara yaitu dengan pendekatan kuantitatif dan kualitatif. Analisis kuantitatif menunjukkan adanya peningkatan hasil belajar matematika siswa mulai dari prapenelitian sampai siklus I yaitu sebesar $31,87 \%$. Berdasarkan kesepakatan peneliti bersama kolaborator keberhasilan tindakan dapat terjadi jika ada peningkatan hasil belajar matematika siswa minimal 20\%. Pada penelitian ini, peningkatan hasil belajar matematika siswa sudah berhasil melampaui $20 \%$, dengan demikian hipotesis penelitian dapat diterima. Hasil penelitian menunjukkan bahwa penerapan langkah-langkah pembelajaran penemuan dalam proses pembelajaran matematika terbukti dapat meningkatkan hasil belajar matematika siswa. Dalam hal ini konsep-konsep materi pelajaran matematika yang bersifat abstrak dapat lebih dipahami siswa dengan adanya pengalaman langsung dan keterlibatan aktif siswa dalam proses pembelajaran penemuan (learning by doing).
\end{abstract}

Kata Kunci : Hasil belajar matematika, pembelajaran penemuan, penelitian tindakan. 


\section{PENDAHULUAN}

Pembelajaran matematika membantu anak dalam mempelajari dan memecahkan permasalahan yang ditemui di dunia sekelilingnya. Selain itu matematika juga dapat melatih anak untuk dapat berpikir logis, teliti, kreatif dan sitematis. Secara khusus pembelajaran matematika bertujuan untuk membantu anak memiliki kemampuan-kemampuan yang meliputi: 1) memahami konsep matematika, menjelaskan keterkaitan antar konsep dan mengaplikasikan konsep atau algoritma, secara luwes, akurat, efisien, dan tepat dalam pemecahan masalah; 2) menggunakan penalaran pada pola dan sifat, melakukan manipulasi matematika dalam membuat generalisasi, menyusun bukti, atau menjelaskan gagasan dan pernyataan matematika; 3) memecahkan masalah yang meliputi kemampuan memahami masalah, merancang model matematika, menyelesaikan model dan menafsirkan solusi yang diperoleh; 4) mengkomunikasikan gagasan dengan simbol, tabel, diagram, atau media lain untuk memperjelas keadaan atau masalah; 5) memiliki sikap menghargai kegunaan matematika dalam kehidupan, yaitu memiliki rasa ingin tahu, perhatian, dan minat dalam mempelajari matematika, serta sikap ulet dan percaya diri dalam pemecahan masalah, (Dharma Bhakti, 2006, p. 30) Mengingat pentingnya pelajaran matematika dalam menunjang keberhasilan anak menghadapi berbagai persoalan yang ditemuinya sehari-hari, maka tepat kiranya jika matematika dijadikan sebagai salah satu syarat kelulusan siswa di sekolah pada berbagai jenjang pendidikan termasuk pada tingkat Sekolah Dasar. The National Council of Teachers of Mathematics Standards (NCTM) menyebutkan bahwa pembelajaran matematika untuk anak usia dini, khususnya usia prasekolah sampai kelas II SD hendaknya dapat memenuhi standar proses yang meliputi problem solving (pemecahan masalah), reasoning and proof (penalaran dan bukti), communication (komunikasi), connections (koneksi), dan representation (representasi). (Jo Ann Brewer, 2007, p. 353)

Dari pernyataan tersebut, pembelajaran matematika bukan sekedar transfer materi, namun dalam pelaksanaannya hendaknya melibatkan kegiatan yang melatih kemampuan anak dalam memecahkan masalah, memahami, mengkomunikasikan, menghubungkan dan merepresentasikan materi yang telah dipelajarinya.

Pada kenyataannya, matematika saat ini masih belum menempati posisi mata pelajaran yang banyak diminati siswa di sekolah. Matematika masih dipandang sebagai mata pelajaran yang sulit dan menakutkan juga membosankan. Berdasarkan hasil studi dokumen hasil belajar matematika kelas II Madrasah Ibtidaiyah Ishlahuddiniyyah, Kecamatan Pondok Aren, Tangerang, didapatkan sebanyak 22 orang siswa dari 32 orang siswa mendapatkan nilai dibawah KKM. Dengan kata lain kemampuan matematika siswa yang belum tuntas mencapai prosentase $68,75 \%$ atau lebih dari $50 \%$.(Hasil studi dokumentasi pra penelitian)

Pembelajaran matematika masih belum melibatkan siswa secara aktif, bersifat hapalan dan kurang pengalaman yang bersifat praktek langsung. Hal tersebut menjadikan pembelajaran matematika membosankan dan menimbulkan kesulitan bagi siswa. Kecenderungan proses pembelajaran matematika masih bersifat konvensional diperkuat dengan hasil observasi proses kegiatan pembelajaran matematika yang dilakukan oleh peneliti pada siswa kelas II Madrasah Ibtidaiyah Ishlahuddiniyyah, Kecamatan Pondok Aren, Tangerang. Hasil observasi menunjukkan pembelajaran dilakukan dengan metode ceramah 
dan penugasan. Dalam menjelaskan materi, guru hanya menggunakan buku paket dan tidak ditambah dengan media lain yang bersifat kongkrit. Proses pembelajaran berjalan kurang efektif, karena bersifat teacher centre. Hal ini juga disebabkan oleh faktor tidak seimbangnya perbandingan antara jumlah siswa dan jumlah guru dalam mengajar. Banyak siswa, terutama yang duduk di bagian belakang tidak terperhatikan oleh guru.

Berdasarkan uraian di atas, pembelajaran matematika khususnya di SD hendaknya tidak hanya bersifat hapalan, namun disesuaikan dengan tujuan pembelajaran matematika dalam rangka mengembangkan keterampilan proses dan melatih kemampuan dalam pemecahan masalah (problem solving). Dalam hal ini, pembelajaran penemuan dapat dijadikan sebagai salah satu pilihan pembelajaran yang sesuai bagi anak. Dalam belajar penemuan, motivasi berasal dari kegiatan itu sendiri dan kegembiraan keterlibatan langsung. Pada penelitian ini dirancang untuk mengkaji tindak pembelajaran penemuan dalam rangka meningkatkan hasil belajar matematika khususnya pada siswa kelas II SD. Melalui penelitian ini diharapkan matematika tidak lagi menjadi mata pelajaran yang sulit dan membosankan.

Berdasarkan latar belakang masalah penelitian di atas, perumusan masalah dalam penelitian ini adalah sebagai berikut: 1) Bagaimanakah proses perencanaan pembelajaran penemuan dalam meningkatkan hasil belajar matematika siswa kelas II Madrasah Ibtidaiyah Ishlahuddiniyah, Kecamatan Pondok Aren, Tangerang ? 2) Apakah hasil belajar matematika siswa kelas II Madrasah Ibtidaiyah Ishlahuddiniyyah, Kecamatan Pondok Aren, Tangerang dapat ditingkatkan melalui pembelajaran penemuan?

\section{METODE PENELITIAN}

\section{Perencanaan dan pelaksaan tindakan}

Penelitian ini menggunakan metode desain penelitian tindakan model Kemmis \& Taggart dengan langkah sebagai berikut: 1) perencanaan (planning); 2) tindakan (acting); 3) observasi (observing); dan 4) refleksi (reflecting). Hubungan antara komponen tersebut menunjukkan sebuah siklus atau kegiatan berulang.

Berdasarkan refleksi, peneliti mendapatkan peningkatan hasil intervensi tindakan dan memungkinkan untuk melakukan perencanaan tindakan lanjutan dalam siklus selanjutnya. Adapun tahapan yang dilakukan : 1) Perencanaan: Merencanakan kegiatan pembelajaran matematika sesuai dengan langkah-langkah pembelajaran penemuan, menyiapkan alat, bahan dan media yang akan digunakan, menyiapkan alat dokumentasi dan instrument yang akan digunakan. 2) Tindakan dan pengamatan: Melaksanakan kegiatan pembelajaran penemuan dalam proses pembelajaran matematika dan melakukan pengamatan dengan mencatat pelaksanaan kegiatan untuk melihat proses keberhasilan pembelajaran yang berupa hasil belajar matematika. 3) Refleksi : Melakukan evaluasi dan membahas hasil evaluasi dengan kolaborator mengenai kegiatan yang dilakukan dan hasil pencapaian hasil belajar matematika yang didapatkan pada siklus I. Berdasarkan kesepakatan dengan kolaborator, penelitian ini dikatakan berhasil apabila terjadi peningkatan atau pencapain prosentase skor hasil belajar matematika siswa minimal sebesar $20 \%$. 


\section{Teknik pengumpulan data}

Jenis instrument pengumpulan data yang digunakan pada penelitia ini adalah tes pemahan materi matematika, tes perbuatan atau observasi, catatan lapangan dan dokumentasi. Instrument tes dan observasi yang digunakan pada penelitian ini ialah instrument tes pemahaman materi matematika dan intrumen observasi. Kedua instrument tersebut sebelum digunakan telah dilakukan validasi pakar untuk melihat kesesuain dan ketepatan instrument. Selalin itu dilakukan uji keterbacaan terhadap siswa di SDI Al Huda, yang kemudian diolah dengan Anates V4.0.5.

\section{Teknik Analisis Data}

Data yang diperoleh dari penelitian ini mencakup dua jenis data, sesuai dengan tuntutan penelitian tindakan kelas, yaitu data kualitatif dan data kuantitatif. Data yang bersifat kualitatif dengan cara menganalisis data dari hasil observasi,tes pemahaman materi, catatan lapangan, dan catatan dokumentasi selama penelitian. Data-data tersebut kemudian dianalisis dengan analisis kualitatif yang dapat dilakukan dengan reduksi data, display dan kesimpulan sesuai pendapat yang diungkapkan oleh Miles dan Huberman.

Analisis data kuantitatif dilakukan diakhir siklus dengan melihat tingkat konsistensi proporsi kenaikan hasil belajar matematika siswa. Rumus studi proporsi nilai rata-rata siswa adalah sebagai berikut:

$\mathrm{P}=\left(\sum \mathrm{x}\right) / \mathrm{N} \times 100 \%$

Keterangan:

$\mathrm{P}=$ proporsi atau perbandingan antara jumlah sampel dengan kemampuan yang dicapai siswa

$\sum \mathrm{x}=$ jumlah skor yang diperoleh siswa

$\mathrm{N}=$ skor maksimal

\section{TINJAUAN PUSTAKA}

\section{Hasil Belajar Matematika}

Secara psikologis, belajar merupakan suatu proses perubahan yaitu perubahan tingkah laku sebagai hasil interaksi dengan lingkungannya dalam memenuhi kebutuhan hidupnya. Dalam hal ini tingkah laku yang baru secara keseluruhan, sebagai hasil pengalamannya sendiri dalam interaksi dengan lingkungannya. (Slameto, 2003, p. 2.)

Selaras dengan pernyataan tersebut, Buber dalam Semiawan menyatakan bahwa dalam belajar, pengetahuan diperoleh melalui suatu dialog yang ditandai oleh suasana belajar yang bercirikan pengalaman dua sisi (two side experience). (Conny R., 2007, p. 4.).

Dari pernyataan-pernyataan tersebut, perubahan perilaku dalam proses belajar terjadi akibat dari interaksi dengan lingkungan. Interaksi biasanya berlangsung secara sengaja. Dengan demikian belajar dikatakan berhasil apabila terjadi perubahan dalam diri individu. Sebaliknya apabila terjadi perubahan dalam diri individu maka belajar tidak dikatakan berhasil. Selain itu dalam prosesnya kegiatan belajar ditandai dengan adanya interaksi/dialog dua arah sehingga pengetahuan dapat tersampaikan. Terkait dengan hasil belajar, Sudjana mengartikan bahwa hasil belajar adalah kemampuan-kemampuan yang dimiliki siswa setelah ia menerima pengalaman belajarnya. Sudjana, Nana, 2011), h. 22. 
Dengan demikian siswa yang berhasil belajar adalah siswa yang berhasil mencapai tujuan-tujuan pembelajaran atau tujuan instruksional. Dalam sistem pendidikan nasional rumusan tujuan pendidikan, baik tujuan kurikuler maupun tujuan instruksional, dalam pelaksanaannya menggunakan klasifikasi hasil belajar Benyamin Bloom yang dibagi dalam tiga kawasan meliputi domain kognitif, afektif, dan psikomotorik. Berdasarkan pernyataan tersebut, tingkat keberhasilan proses belajar seseorang dapat dilihat dari ada tidaknya perubahan pada salah satu atau ketiga domain yang meliputi aspek kognitif, afektif dan psikomotor.

Pada penelitian ini akan dibatasi penjelasan hasil belajar pada ranah kognitif saja, mengingat pada penelitian ini, hasil belajar yang diteliti dibatasi pada pencapaian skor hasil belajar yang bersifat kognitif. Hasil belajar pada ranah kognitif menurut Bloom terdiri dari enam jenjang secara hierarkis meliputi hafalan/pengetahuan $(\mathrm{C} 1)$, pemahaman $(\mathrm{C} 2)$, penerapan $(\mathrm{C} 3)$, analisis (C4), sintesis (C5) dan evaluasi (C6). (Hamzah B. Uno dan Satria Koni. 2012, p. 60.)

Keenam jenjang kemampuan tersebut merupakan subkategori dari ranah kognitif yang berurutan secara hirarkis (bertingkat), mulai dari tingkah laku yang sederhana sampai tingkah laku yang paling kompleks.

Matematika merupakan cabang ilmu pengetahuan yang eksak dan terorganisir secara sistematik. Matematika merupakan suatu alat yang dapat memperjelas dan menyederhanakan suatu keadaan atau situasi melalui abstraksi, idealisasi, atau generalisasi untuk suatu studi ataupun pemecahan masalah. Definisi yang hampir senada diuraikan dalam kurikulum 2004 yang memberikan pengertian bahwa matematika merupakan suatu bahan kajian yang memiliki objek abstrak dan dibangun melalui proses penalaran deduktif, yaitu kebenaran suatu konsep diperoleh sebagai akibat logis dari kebenaran sebelumnya sehingga keterkaitan antar konsep dalam matematika bersifat sangat kuat dan jelas. (Departemen Pendidikan Nasional, 2003, p. 5) Dari pernyataan tersebut, matematika memiliki bahasa dan aturan yang terdefinisi dengan baik, penalaran yang jelas dan sistematis, dan struktur atau keterkaitan antar konsep yang kuat.

Pembelajaran matematika membantu anak dalam mempelajari dan memecahkan permasalahan yang ditemui di dunia sekelilingnya. Pembelajaran matematika bertujuan untuk melatih dan menumbuhkan cara berpikir secara sistematis, logis, kritis, kreatif dan konsisten. Selanjutnya, The curriculum Standards for School Mathematics yang dipublikasikan oleh The National Council of Teachers of Mathematics (NCTM) menekankan tujuan pembelajaran matematika bagi siswa sebagai berikut:

learning to value mathematics, becoming confident in one's own ability, becoming a mathematical problem solver, learning to communicate mathematically, and learning to reason mathematically. (Charlesworth, Rosalind dan Karen K. Lind, 1990, p.11).

Berdasarkan pernyataan tersebut, tujuan pembelajaran matematika diharapkan dapat membantu siswa untuk mampu menghargai dan memahami matematika bukan saja sebagai pengetahuan namun mendorong siswa untuk dapat memecahkan masalah-masalah matematika dalam kehidupan sehari-hari untuk kemudian mengkomunikasikan dan mengaplikasikannya. Tujuan pembelajaran 
matematika tersebut dapat dicapai siswa melalui pendekatan konkret. Dengan kata lain, pengalaman langsung dan keaktifan siswa menjadi kunci utamanya. Ruang lingkup pembelajaran matematika untuk siswa kelas II SD pada semester II meliputi kompetensi dasar melakukan perkalian bilangan sampai dua angka, melakukan pembagian bilangan dua angka, dan melakukan operasi hitung campuran. Pada penelitian ini,materi pembelajaran matematika dibatasi pada kompetensi dasar melakukan perkalian bilangan sampai dua angka. Selanjutnya, The National Council of Teachers of Mathematics Standards (NCTM) menyatakan bahwa dalam merencanakan suatu pembelajaran matematika, guru hendaknya mengacu pada kerangka standar kurikulum yang sesuai dengan tahapan usia siswa, sebagai berikut:

...for preschool through second grades (Pre-K-2) include five content standards and five process standards. Content standards of mathematics are: 1) number and operations, 2) geometry and spatial sense, 3) measurement, 4) patterns, functions, and algebra, 5) data analysis, statistics, and probability. Process standards of mathematics are: 1) problem solving, 2) reasoning and proof, 3) communications, 4) connections, 5) representation.

Berdasarkan pernyataan di atas, dapat diartikan bahwa kerangka standar kurikulum matematika pada tingkat usia Prasekolah sampai dengan kelas II SD meliputi standar isi dan standar proses matematika. Standar isi matematika meliputi: (1) bilangan dan operasi hitung, (2) geometri dan pengertian ruang, (3) pengukuran, (4) pola, fungsi, dan aljabar, (5) analisis data, statistika, dan peluang. Standar proses matematika meliputi: (1) pemecahan masalah, (2) penalaran dan bukti, (3) komunikasi,(4) koneksi, dan (5) representasi. Dalam memberikan pengalaman matematika bagi anak usia dini, standar isi dan standar proses matematika tidak dapat dipisahkan, karena keduanya saling terhubung dan terjalin menjadi satu kesatuan dalam kurikulum secara keseluruhan. Proses pembelajaran di kelas mempunyai tujuan yang bersifat mengikat, artinya diketahui secara jelas dan operasional oleh guru dan siswa. Terkait dengan hal tersebut, hasil belajar siswa di sekolah dapat diartikan sebagai tingkat pencapaian siswa terhadap tujuan pembelajaran yang meliputi aspek kognitif, psikomotor dan afektif setelah mengikuti proses belajar. Berdasarkan uraian tersebut, dapat disimpulkan bahwa hasil belajar matematika siswa kelas II SD pada penelitian ini dibatasi pada perubahan kemampuan matematika siswa pada dimensi kognitif yang meliputi kemampuan mengenal (C1), memahami (C2), mengaplikasikan (C3), menganalisis (C4) materi matematika setelah siswa mengikuti proses belajar matematika.

Jika dikaitkan dengan standar proses matematika, hasil belajar matematika siswa kelas II SD mencakup perubahan kemampuan siswa dalam mengenal, memahami, menerapkan dan menganalisis materi matematika berdasarkan standar proses matematika. Dimana standar proses matematika yang dimaksud dalam penelitian ini dibatasi pada aspek: 1) pemecahan masalah, 2) penalaran dan bukti, 3) komunikasi.

Pembelajaran penemuan adalah proses mental dimana siswa mengasimilasi suatu konsep atau suatu prinsip. Proses mental tersebut misalnya mengamati, menggolongkan, membuat simpulan dan sebagainya. Selanjutnya, Moore mengungkapkan definisi senada mengenai pembelajaran penemuan, sebagai berikut: 
Discovery learning is means by which students engage in problem solving in developing knowledge or skills. Discovery learning is intentional learning through supervised problem solving following the scientific method investigation.. (Kenneth D. Moore, 2005, p. 295).

Pembelajaran penemuan adalah sarana bagi siswa terlibat dalam pemecahan masalah dalam pengembangan pengetahuan atau keterampilan. Pembelajaran penemuan adalah pembelajaran yang disengaja melalui pemecahan masalah yang diawasi mengikuti metode penyelidikan ilmiah. Dari pernyataan tersebut menunjukkan bahwa dalam pembelajaran penemuan keaktifan siswa dalam proses belajar merupakan hal yang diutamakan, dengan kata lain proses pembelajaran yang ditekankan bersifat student centre bukan teacher centre. Dalam pembelajaran penemuan, motivasi belajar siswa diharapkan dapat muncul dari dalam diri siswa sendiri sebagai dampak dari kesenangan dan fleksibilitas yang seharusnya ada dalam pembelajaran penemuan. Hal tersebut dipertegas dengan pernyataan Harlen sebagai berikut:

Discovery learning emerged from the desire to give pupils the excitement of finding things out for themselves, following in the footsteps of scientists. it was a reaction to the formal transmission of knowledge from teacher to pupil in which there was no room for the experience of participating in science.

Pembelajaran penemuan muncul dari keinginan untuk memberikan siswa kegembiraan menemukan hal-hal untuk diri siswa sendiri, mengikuti jejak para ilmuwan. itu adalah reaksi terhadap transmisi formal pengetahuan dari guru kepada murid dimana tidak ada ruang bagi pengalaman berpartisipasi dalam ilmu pengetahuan. Berdasarkan beberapa uraian mengenai pengertian pembelajaran penemuan di atas, maka dapat dideskripsikan bahwa pembelajaran penemuan merupakan proses pembelajaran aktif yang disengaja melalui pemecahan masalah yang diawasi mengikuti metode penyelidikan ilmiah. Moore secara lebih khusus menyatakan tahapan pembelajaran penemuan yang mengacu pada metode penyelidikan ilmiah yang meliputi: 1) identify problem (mengidentifikasi masalah); 2) develop possible solutions (mengembangkan kemungkinan solusi); 3) collect data (mengumpulkan data); 4) analyze and interpret data (analisis dan interpretasi data); 5) test conclusions (uji kesimpulan). (Moore, 2005: 296) Berdasarkan uraian tersebut, pada tahap mengidentifikasi masalah, guru membimbing siswa untuk menyadari masalah yang ada dan menulis pernyataan masalah. Pada tahap mengembangkan kemungkinan solusi, siswa dibimbing untuk dapat mengusulkan solusi. Pada tahap mengumpulkan data terdiri dari mengumpulkan bukti, melakukan percobaan, dan survei sampel. Pada tahap analisis dan interpretasi data terdiri dari mengembangkan data yang didukung pernyataan bermakna, menguji hipotesis, membangun hubungan atau pola, dan membuat generalisasi. Terakhir, pada tahap uji kesimpulan siswa dibimbing untuk mendapatkan data baru dan merevisi kesimpulan asli.

Berdasarkan kelima tahapan metode penyelidikan ilmiah yang telah diuraikan di atas, pada implikasinya dalam proses pembelajaran Djamarah dan Zain merincinya menjadi langkah-langkah pembelajaran penemuan yang meliputi: stimulus (stimulation), perumusan/identifikasi masalah (problem statement), pengumpulan data (data collection), pengolahan data (data 
prossesing), pembuktian (verification), generalisasi (generalization). (Syaiful Bahri Djamarah, 2002, pp. 22-23)

\section{HASIL DAN PEMBAHASAN}

Indikator keberhasilan dalam penelitian tindakan ini adalah adanya peningkatan hasil belajar matematika siswa minimal sebersar $20 \%$. Hasil penelitian tindakan ini menunjukkan bahwa hasil belajar matematika siswa meningkat dengan adanya tindakan berupa penerapan pembelajaran penemuan dalam pembelajaran matematika. Peningkatan hasil belajar matematika siswa dapat dilihat melalui data kuantitatif yang dihasilkan dari hasil tes pemahaman materi dan hasil pengamatan terhadap kegiatan pembelajaran matematika siswa yang berlangsung pada siklus I. Berdasarkan hasil tes pemahaman materi, menunjukkan bahwa hasil belajar metematika siswa telah meningkat sesuai target pada penelitian ini. Hasil belajar matematika secara individu maupun rata-rata kelas telah mencapai peningkatan sebesar $20 \%$ lebih. Prosentase peningkatan hasil belajar matematika tertinggi adalah sebesar 50\%, dan prosentase peningkatan hasil belajar matematika terendah adalah sebesar 20\%. Hal tersebut menunjukkan bahwa target peningkatan hasil belajar matematika siswa yaitu minimal sebesar $20 \%$ telah tercapai pada siklus I.

Berdasarkan hasil pengamatan, kemampuan proses matematika seluruh siswa secara individu maupun rata-rata kelas telah mengalami peningkatan diatas target yang ditetapkan peneliti dan kolaborator yaitu minimal 20\%. Prosesentase peningkatan hasil belajar matematika tertinggi mencapai $35 \%$ dan prosentase peningkatan terendah sebesar 20\%. Selain itu, dalam prosesnya, langkah-langkah pembelajaran membantu siswa untuk meningkatkan kemampuan proses matematika. Kemampuan proses matematika dalam penelitian ini didasarkan pada standar proses matematika yang meliputi aspek pemecahan masalah, aspek penalaran dan bukti dan aspek komunikasi. Melalui langkah-langkah pembelajaran penemuan, siswa lebih memiliki kesempatan untuk melatih kemampuan proses matematika. Pembelajaran penemuan memberikan kesempatan kepada siswa untuk dapat lebih bereksplorasi dalam berpikir dan bertindak terhadap materi yang sedang dipelajari. Karakteristik siswa SD kelas awal yang merupakan anak usia dini cenderung sangat menyukai kegiatankegiatan pembelajaran yang memberikan kesempatan kepada siswa untuk terlibat langsung. Misalnya dalam memahami konsep perkalian yang dihubungkan dengan konsep penjumlahan, siswa akan lebih mudah memahami ketika pembelajaran terhadap materi tersebut dilakukan dengan membuat "mozaik perkalian". Kegiatan ini memberikan pengalaman langsung yang melatih siswa memahami materi secara lebih jelas. Dengan demikian, secara otomatis kemampuan proses matematika siswa yang meliputi pemecahan masalah, penalaran dan bukti serta komunikasi akan terlatih.

Selaras dengan uraian di atas, berdasarkan hasil tindakan pada penelitian ini, telah terjadi peningkatan yang signifikan pada kemampuan proses matematika siswa. Secara kuantitatif, pada kemampuan proses matematika aspek pemecahan masalah sebanyak $86.36 \%$ siswa mengalami peningkatan melampaui $20 \%$. Selanjutnya pada aspek penalaran dan bukti seluruh siswa telah mengalami peningkatan lebih dari $20 \%$. Begitupun pada aspek komunikasi, seluruh siswa juga telah mengalami peningkatan lebih dari $20 \%$. 
Secara kualitatif, peningkatan kemampuan proses matematika siswa pada aspek pemecahan masalah ditunjukkan dengan meningkatnya kemampuan siswa dalam menyelesaikan soal-soal perkalian baik secara konkret maupun abstrak. Secara konkret, siswa dapat menyelesaikan soal perkalian dengan menggunakan bantuan media kancing. Sedangkan secara lebih abstrak pada pertemuan keenam siswa sudah dapat menyelesaikan soal-soal cerita yang berhubungan dengan perkalian. Selain itu, siswa juga dapat mengidentifikasi soal-soal perkalian dari sebuah cerita. Hal tersebut menunjukkan bahwa selama siklus I telah terjadi perkembangan dan peningkatan kemampuan proses matematika siswa pada aspek pemecahan masalah secara bertahap. Selanjutnya peningkatan kemampuan proses matematika siswa pada aspek penalaran dan bukti ditunjukkan ketika siswa sudah mulai dapat mengungkapkan alasan-alasan yang logis terhadap jawaban atau pendapat yang disampaikannya. Terkait dengan hal ini, siswa SD kelas awal yang merupakan anak usia dini cenderung masih sulit untuk mengungkapkan pendapat atau alasan dari jawaban yang diberikan. Namun melalui langkahlangkah dalam pembelajaran penemuan, siswa dibimbing dan diarahkan untuk dapat kritis dalam berpikir. Hal ini selaras dengan karakteristik siswa yang serba ingin tahu.

Melalui kegiatan diskusi dan tanya jawab yang merupakan ciri khas dari pembelajaran penemuan, siswa memiliki kesembatan untuk memberikan ide, pendapat dan bertanya tentang materi yang sedang dipelajari. Selain itu dalam hal pemahaman terhadap materi, khususnya pokok bahasan perkalian, siswa sudah dapat memahami hubungan antara konsep perkalian dan penjumlahan yang diaplikasikan dengan membuat mozaik perkalian. Selanjutnya secara fisik siswa dapat mengaplikasikan pemahamannya terhadap perkalian dengan mampu membentuk kelompok sesuai instruksi perkalian yang disebutkan guru. Hal tersebut menunjukkan bahwa proses berpikir dan bernalar siswa berkembang dan meningkat seiring dengan pembiasaan berupa kegiatan diskusi dan tanya jawab dalam proses pembelajaran.

Kegiatan diskusi dan tanya jawab yang dilakukan selama proses pembelajaran menstimulasi siswa untuk dapat berpikir dan bernalar dengan lebih kaya dan mendalam. Terakhir peningkatan kemampuan proses matematika siswa pada aspek komunikasi ditunjukkan dengan munculnya keberanian siswa untuk menjawab pertanyaan guru, memberikan pendapat terhadap materi yang sedang dipelajari dan sikap antusias serta fokus belajar siswa yang meningkat ketika mengikuti proses pembelajaran. Selanjutnya kemampuan siswa dalam komunikasi juga ditunjukkan ketika siswa membuat grafik perkalian menggunakan benda-benda sekitar yang menunjukkan siswa dapat menterjemahkan serta merepresentasikan bentuk perkalian kedalam bentuk lain contohnya grafik. Kemampuan siswa dalam aspek komunikasi didukung oleh peran guru sebagai fasilitator yang mendorong keaktifan siswa dalam proses pembelajaran sehingga pembelajaran berjalan dengan lebih hidup dan menyenangkan.

\section{KESIMPULAN}

Berdasarkan analisis terhadap tindakan berupa proses pembelajaran matematika melalui pebelajaran penemuan dalam upaya meningkatkan hasil belajar matematika siswa kelas II MI Ishlahuddiniyyah Pondok Aren, Tangerang, didapatkan kesimpulan sebagai berikut: 
Prosentase peningkatan hasil belajar matematika siswa dari pra-penelitian ke siklus I sebesar 31,87\%. Dimana pada pra-penelitian prosentase rata-rata hasil belajar matematika siswa sebesar $46,36 \%$ meningkat pada siklus I menjadi sebesar 78,23\%. Hal ini membuktikan bahwa kriteria keberhasilan penelitian tindakan yang telah disepakati peneliti bersama kolaborator yaitu adanya peningkatan hasil belajar matematika minimal sebesar $20 \%$ telah tercapai. Dengan demikian maka dapat disimpulkan bahwa penelitian tindakan ini berhasil dan hipotesis penelitian diterima. 2) Peningkatan hasil belajar matematika siswa pada penelitian tindakan ini juga didukung oleh meningkatnya kemampuan proses matematika siswa. Dalam proses pembelajaran matematika, hal-hal positif yang timbul ketika diterapkannya langkah-langkah pembelajaran penemuan memberikan dampak positif pula terhadap kemampuan proses matematika siswa. Peningkatan kemampuan proses matematika secara keseluruhan jika dilihat mulai dari prapenelitian sampai siklus I mencapai prosentase sebesar 28,51\%. Dimana pada pra-penelitian prosentase rata-rata kemampuan proses matematika sebesar 43,62\% meningkat pada siklus I menjadi 72,13\%. Hal tersebut membuktikan bahwa penerapan pembelajaran penemuan dapat meningkatkan kemampuan proses matematika.

\section{DAFTAR PUSTAKA}

\section{Buku:}

Abdurrahman,Mulyono. Pendidikan Bagi Anak Berkesulitan Belajar. Jakarta: Depdikbud

Brewer,Jo Ann Introduction to Early Childhood Education, Preschool through Primary Grades, Sixth Edition. USA: Pearson education, 2007.

Charlesworth, Rosalind dan Karen K. Lind, Math and Science for Young Children. USA: Delmar Publishers, 1990.

Djamarah, Syaiful Bahri dan Aswan Zain, Strategi Belajar Mengajar. Jakarta: Rineka Cipta, 2002.

Harlen,Wynne. The Teaching of Science. Great Britain: David Fulton Publishers, 1992.

Jihad, Asep dan Abdul Haris. Evaluasi Pembelajaran. Yogyakarta: Multi Pressindo, 2010.

Moore, Kenneth D. Effective Instructional Strategies: From Theory to Practice. USA:Sage Publications, 2005.

Slameto, Belajar dan Faktor-faktor yang Mempengaruhinya. Jakarta: Rineka Cipta, 2003.

Semiawan,Conny R. Landasan Pembelajaran dalam Perkembangan Manusia. Jakarta: Pusat Perkembangan Kemampuan Manusia, 2007.

Sudjana,Nana. Penilaian Hasil Proses Belajar Mengajar. Bandung: Remaja Rosdakarya, 2011.

Uno, Hamzah B. dan Satria Koni. Assessment Pembelajaran. Jakarta: Bumi Aksara, 2012.

\section{Dokumen :}

Kurikulum Berbasis Kompetensi Mata Pelajaran Matematika Sekolah Menengah Umum. Jakarta : Pusat Kurikulum, 2001. 
Kurikulum 2004, Standar Kompetensi Mata Pelajaran Matematika Sekolah Dasar dan Madrasah Ibtidaiyah. Jakarta: Departemen Pendidikan Nasional, 2003.

Panduan Kurikulum Tingkat Satuan Pendidikan (KTSP) SD/ MI. Jakarta: BP. Dharma Bhakti,2006. 